\title{
A review of the trends in Ghana's power sector
}

\author{
Maame Esi Eshun ${ }^{*}$ and Joe Amoako-Tuffour
}

\begin{abstract}
Power generation in Ghana has gone through a number of phases: starting with diesel generators and stand-alone electricity supply systems owned by industrial mines and factories, to the hydro phase following the construction of the Akosombo dam, and now to a thermal complement phase powered by gas and/or light crude oil. A power crisis has also become a perennial development challenge in Ghana, with increasing severity that threatens the country's economic growth and transformation. The troubling rationing system, the slowdown in industrial activity, job and income losses, and disruptions in social life are telling reminders of what now seems a perennial drag on Ghana's development agenda. While Ghana has committed itself to universal electricity access by 2020, the real challenge is the capacity to meet this goal and, most important, to ensure that supply is reliable and adequate. This paper outlines the state of current electricity demand and supply gap and the major impediments to resolving the supply bottlenecks and in managing demand, highlights institutional and regulatory constraints, and identifies some key issues that should be the focus of policy decision-making going forward.
\end{abstract}

Keywords: Energy supply, Energy demand, Supply capacity, Energy policy, Ghana

\section{Review}

Access to electricity, coupled with aggressive industrialization, is a key component in achieving sound economic development. Electricity is needed to maintain law and order, security, and stability [1]. From an economic point of view, the production of all goods and services and the development of economic infrastructure all depend on a reliable and sustainable supply of electrical energy.

Electricity generation in Ghana has gone through a number of phases: starting with diesel generators and stand-alone electricity supply systems owned by industrial mines and factories, to the hydro phase following the construction of the Akosombo dam, and now to a thermal complement phase powered by gas and/or light crude oil. An electricity crisis has also become a perennial development challenge in Ghana, with increasing severity that threatens the country's economic growth and transformation. The troubling rationing system, the slowdown in industrial activity, job and income losses, and disruptions in social life are telling reminders of

\footnotetext{
* Correspondence: meeshun@acetforafrica.org

Research Department, African Center for Economic Transformation, Accra,
} Ghana

\section{Springer}

(c) 2016 Eshun and Amoako-Tuffour. Open Access This article is distributed under the terms of the Creative Commons Attribution 4.0 International License (http://creativecommons.org/licenses/by/4.0/), which permits unrestricted use, distribution, and reproduction in any medium, provided you give appropriate credit to the original author(s) and the source, provide a link to the Creative Commons license, and indicate if changes were made. ment agenda.

The Institute of Statistical, Social and Economic Research (ISSER) in 2014 estimated Ghana to lose between $\$ 320$ million and \$924 million per annum in productivity and economic growth due to the current power crises [2]. The Wholesale Power Reliability Assessment report (2010) also estimated that Ghana loses between 2 and $6 \%$ of gross domestic product (GDP) annually due to inadequate and unreliable power supply. ${ }^{1}$ Thus, with the economic costs of inadequate power supply, a reliable and adequate supply of power becomes even more pressing.

While Ghana has committed itself to universal electricity access by 2020 , the real challenge is the capacity to meet this goal and, most important, to ensure that supply is reliable and adequate. Respective governments have also failed in their preparation towards building a sustainable and resilient power hub to cater for the incessant power demand. Especially for a lower middleincome country like Ghana, it is important to recognize the growth of industries and the increasing population growth in relation to the increase in power demand. 
This paper outlines the trends and state of Ghana's current power demand and supply and the major impediments to resolving the supply bottlenecks and in managing demand; highlights power supply capacity constraints, growth, and development implications; and identifies some key issues that should be the focus of policy decision-making going forward. This paper begins with some background and expounds on the current electricity situation by highlighting the demand drivers and the supply-demand mismatch, the challenges, the energy sector initiatives implemented over the years, and the growth and development implications. Finally, the paper discusses the demand- and supply-side options available with alternatives in the energy mix and a focus on private sector participation.

\section{A brief history of the trends in the Ghanaian power sector}

After Ghana secured independence in 1957, the impetus to embark on the massive industrialization of building roads, schools, hospitals, and factories called for a reliable supply of power. The need to build a dam to provide the country with hydropower was born. The government sourced loans from the World Bank and the USA (VALCO specifically) to execute the project. As a result, the Volta River Authority (VRA) was established in 1961 and charged with the duties of electricity generation via the water power of the Volta River, the construction of the Akosombo dam and a power station near Akosombo, and the resettlement of residents. ${ }^{2}$ Formal construction of the dam commenced in 1962 and was completed in 1965 at an estimated cost of \$200 million [3].

Rapid import industrialization followed the construction of the dam in Ghana's major cities, thus increasing the demand for power. By 1968, electricity demand peaked at $540 \mathrm{GWh}$ (see Fig. 1). Total generating capacity of the Akosombo dam by 1972 had reached $3321.23 \mathrm{GWh}$ with the installation of two additional generating units. Domestic power consumption increased nearly sixfold from $540 \mathrm{GWh}$ in 1968 to 3917 GWh by 1976 with an annual growth rate of about $10 \%$. Domestic power consumption, however, fell from 3917 GWh in 1976 to 3429 GWh in 1978 and declined further to about $1151 \mathrm{GWh}$ in 1984 (VRA Annual Report, 1966-1990) as a result of the deteriorating economy in the late 1970s and early 1980s [4] (see Fig. 1).

With the growing demand for electricity by 1971, the VRA commissioned a study on alternative means of meeting those demands which led to the construction of the Kpong Hydroelectric Project, formally commissioned in 1982 and giving an additional capacity of $160 \mathrm{MW}$ [5]. In 1972, with an electricity generation capacity of 3321.23 GWh, VRA began to supply electricity to Togo and Benin following the construction of a $205-\mathrm{km} 161$ $\mathrm{kV}$ transmission line from Akosombo to Lome [2]. Between 1965 and 1972, the combined power of the Akosombo and Kpong plants meant that Ghana was able to meet its domestic and industrial power needs and also to be an exporter of electricity.

The first power crisis in 1984, compounded by a major drought from 1983, disrupted the generating capability of the Akosombo dam [2]. Total inflow into the dam between 1982 and 1984 was less than $15 \%$ of the expected total, and this triggered power rationing and a reduction of supply to neighboring countries Togo and Benin. Electricity supplied decreased from 5180 GWh in 1981 to $1670 \mathrm{GWh}$ in 1984 while consumption during the same period decreased from $4652 \mathrm{GWh}$ to $1151 \mathrm{GWh}$. Meanwhile, the impact of the Economic Recovery Programme in 1983, coupled with emerging industries

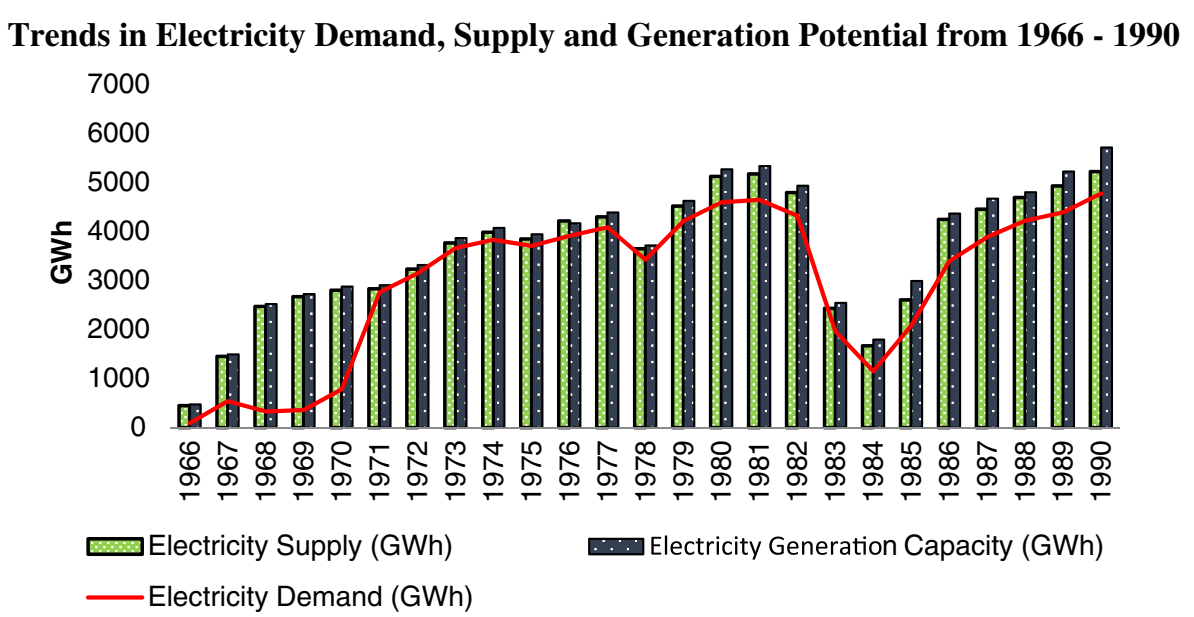

Fig. 1 Trends in electricity demand, supply, and generation potential from 1966 to 1990. Source: Data from VRA Annual Reports (1966-1990) 
and urbanization, significantly increased the demand for power from 1985. Power consumption picked up and increased from $2083 \mathrm{GWh}$ in 1985 to about $4780 \mathrm{GWh}$ in 1990 (see Fig. 1).

Another power crisis in 1998, largely attributed to low rainfalls and inflows to the Volta Lake, resulted in another round of power rationing [2]. Electricity supply to consumers significantly fell to about $4942 \mathrm{GWh}$ in 1998 while consumption dipped from $5110 \mathrm{GWh}$ in 1991 to 4965 GWh in 1998, closely outstripping available electricity supply in that year (see Fig. 2).

\section{Methods}

This paper is an argumentative and reviewed reflection of the electricity situation in Ghana from the 1960s to date. The three main data sources used for the paper were obtained from the Energy Commission of Ghana, annual reports of the Volta River Authority of Ghana, and the World Bank. Other data sources used were official documents in the domains of electricity policy, desk research, and literature online. Based on the data gathered, the demand and supply dynamics of the power sector and the challenges confronting the sector were reviewed. Part of the review involved qualitative descriptions and analysis, as well as an overview of power sector initiatives and policy decisions undertaken in Ghana, and the way forward.

Focusing on the electricity situation makes an interesting case, since the Institute of Statistical, Social and Economic Research (ISSER) in 2014 estimated Ghana to lose between $\$ 320$ million and $\$ 924$ million per annum in productivity and economic growth due to the current energy crises [2]. The Wholesale Power Reliability Assessment report (2010) also estimated that Ghana loses between 2 and $6 \%$ of gross domestic product (GDP) annually due to inadequate and unreliable power supply. ${ }^{3}$ Hence more pressing, is a reliable and adequate supply of power. The troubling rationing system, the slowdown in industrial activity, job and income losses, and disruptions in social life are telling reminders of what now seems a perennial drag on Ghana's development agenda.

\section{The current electricity situation}

Ghana generates about $64 \%$ of its electrical power from hydro sources. Electricity is the dominant form of modern energy used in Ghana, accounting for about $65 \%$ of the energy used in the industrial and service sectors and about $36 \%$ in residential use. ${ }^{4}$

\section{The demand drivers}

Ghana's year-on-year power demand grows by 10 to $15 \%$ with supply generally not meeting set targets. ${ }^{5}$ The expanding industrial sector, service sector-especially in banking, communication, and hospitality services-rapid urbanization, the growth of the middle class, and growing incomes, together with overall population growth (about $2.3 \%$ per annum), have become major drivers of increasing electricity demand. Growth in total power demand has more than doubled between 2003 and 2013 . From a low base in 2000, annual non-residential power demand growth has risen from an average of $9 \%$ between 2000 and 2010. Residential power demand growth has increased overall by $6.2 \%$ per annum between 2000 and 2010 and increased by $15.4 \%$ in 2013 alone. Industry also recorded an average power demand growth rate of $2.2 \%$ between 2000 and 2010 and $9.7 \%$ between 2010 and 2013 but declined to about $1.7 \%$ in 2013 (see Table 1). The decline in industry demand is explained in part by the diminishing share of industry in GDP, from $25 \%$ in 2000 to $19 \%$ in 2010.

Ghana's Energy Commission (2014), ${ }^{6}$ has identified the potential drivers of electricity consumption as industrial growth, petroleum up-stream and mid-stream activities,

Trends in Electricity Supply and Consumption between 1990 and 1999

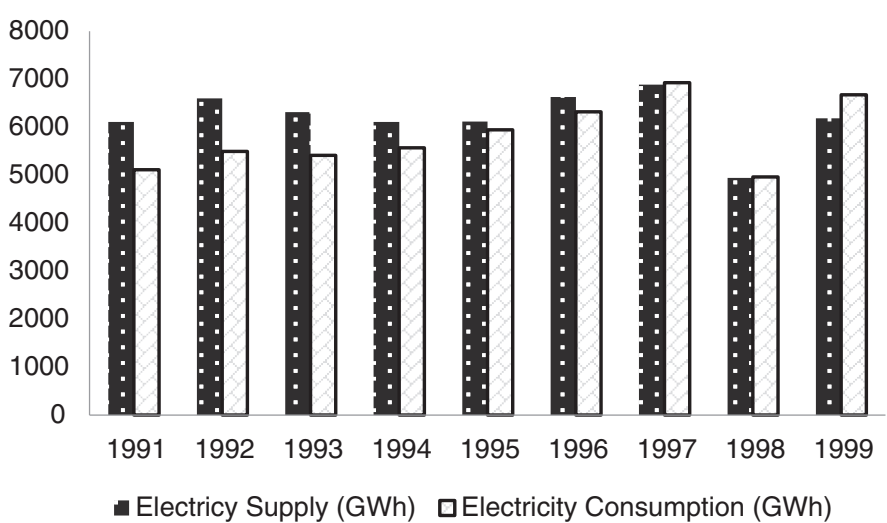

Fig. 2 Trends in electricity supply and consumption between 1990 and 1999. Source: Data from VRA annual reports (1990-1999) 
Table 1 Average annual growth in power demand

\begin{tabular}{llll}
\hline & $2000-2010$ & $2010-2013$ & 2013 \\
\hline Industry & 2.2 & 9.7 & 1.7 \\
Non-residential & 8.9 & 16.5 & 33 \\
Residential & 6.2 & 7.8 & 15.4 \\
\hline
\end{tabular}

Data source: Energy Commission, Ghana

mining, ongoing electrification scheme, and energy conservation and efficiency measures. The rapid expansion of the four major cities, Accra, Tema, Takoradi, and Kumasi, has also been key drivers of residential demand for electricity. Overall, Ghana's population is projected to rise from the 2010 estimate of 25 million to about 40 million by $2030{ }^{7}$

Ghana's electricity consumer base, as at 2010, exceeded 2 million residential consumers and 1150 industrial consumers. ${ }^{8}$ In 2014, the peak power demand of electricity increased from $1943 \mathrm{MW}$ in 2012 to $2061 \mathrm{MW}$ in 2014. ${ }^{9}$ Given the pace of increment in peak power demand, Ghana requires a generation capacity of between 16,398 and $17,350 \mathrm{GWh}$. This translates into an additional capacity requirement of 4000 to 4200 MW to keep up with the incessant demand currently. ${ }^{10}$

\section{Supply capacity}

Frequent nationwide power outages and load shedding are indicative of the supply-demand mismatch. According to the World Economic Forum's Global
Competitiveness Report 2013-2014, Ghana ranks 114th in the quality of electricity supply and scores 3.0 (below the word's mean average of 4.5) in terms of sufficiency and reliability of electricity.

Since the first power crises in 1984, drought and reduced water levels have been the primary cause of the shortfalls in the generating capacity and supply of energy. Increasingly, rising crude oil prices, a patchwork of government policies, mismanagement, corruption, neglect, the monopoly of the energy sector, and obsolete energy infrastructure have become major contributory factors to the supply shortfalls. Since 2013, about $64 \%$ of the country's energy supply is generated from hydro while $35 \%$ is generated from the thermal plants (see Table 2).

The 2015 projections from the Energy Commission indicate a marginal increase in the installed capacity of electricity. The projections also show that most of the power sources will maintain their generating capacity in 2015 (see Table 2). Given the historic dependency of Ghana on hydro (with relatively unchanged generating capacities) and the trend in current power consumption, what is more troubling is for the thermal plants (with relatively little addition to the generating capacity in 2015) to operate under capacity.

\section{Challenges}

The power sector faces a host of challenges, including inadequate power supply infrastructure that requires huge investment, over-reliance on hydro and gas,

Table 2 Electricity generation (2014 and projections for 2015)

\begin{tabular}{|c|c|c|c|c|}
\hline \multirow[t]{2}{*}{ Generating station/plant } & \multicolumn{2}{|c|}{ Installed capacity, MW } & \multicolumn{2}{|c|}{ Dependable capacity, MW } \\
\hline & 2014 & 2015 & 2014 & 2015 \\
\hline \multicolumn{5}{|l|}{ Hydro } \\
\hline Akosombo & 1020 & 1020 & 960 & 900 \\
\hline Kpong & 160 & 160 & 140 & 140 \\
\hline Bui & 400 & 400 & 380 & 380 \\
\hline \multicolumn{5}{|l|}{ Thermal } \\
\hline TAPCO & 330 & 330 & 300 & 300 \\
\hline $\mathrm{TICO}$ & 220 & 330 & 200 & 300 \\
\hline TT1PP & 126 & 126 & 110 & 110 \\
\hline TТ2PP & 49.5 & 49.5 & 45 & 45 \\
\hline MRP & 80 & 80 & 40 & 76 \\
\hline T3 & 132 & 0 & 120 & 0 \\
\hline Sunon-Asogli & 200 & 380 & 180 & 340 \\
\hline CENIT & 126 & 126 & 110 & 110 \\
\hline \multicolumn{5}{|l|}{ Renewables } \\
\hline Solar & 2.5 & 2 & $22 . .5$ & 21 \\
\hline Total & 2946.0 & 3003.5 & 2807.5 & 2722 \\
\hline
\end{tabular}

Source: Energy Commission (2014 and 2015) 
inadequate access to electricity, high cost of fuel for electricity generation, transmission and distribution losses, an inadequate regulatory capacity, enforcement, operational and management difficulties, and vulnerability to climate change. Future power development faces great challenges due to rising living standards and increasing demand for cleaner energy.

\section{Limited generation capacity of power plants}

The supply challenges of Ghana's power sector are mainly seen in the periodic hydrological shortfalls as a result of the uncertain pattern on rainfall and inflows into the hydropower facilities. Relying on rainfall to supply water to the hydro dams to generate power may not be optimal due to changing climate patterns. According to the Energy Commission (2014) ${ }^{11}$ higher inflows into the hydropower facilities would have improved the overall power generation in 2013 amidst the limited gas supply from Nigeria.

The limited water inflows induce the country to rely on thermal power plants fueled by oil and gas. The inability of these plants to attain full generation capacity due to limited and expensive fuel supply inhibits frequent power supply. Supply of gas in 2014, at best, was limited to between 30 and 50 million standard cubic feet per day (mmscfd) as against the contractually agreed volume of 123 mmscfd from Nigeria to power the thermal plants. The deficit in gas supply has necessitated the use of crude oil by VRA which has also proved costly in recent times. ${ }^{12}$ As a result, the thermal plants are unable to run efficiently and at full capacity decreasing the power supply.

The weak financial position of VRA, the Electricity Company of Ghana (ECG), and the Ghana Grid Company Ltd. (GRIDCo), coupled with obsolete infrastructure, has resulted in huge load pressure partly responsible for blackouts. The Tema Oil Refinery's (TOR) processing capacity since its establishment in 1963 has largely remained the same, and it is not able to import and process enough crude oil to meet demand [1].

\section{Cost}

Generally, utility companies operate as natural monopolies due to significant economies of scale that exist in the industry. As a result, most energy companies operate as state monopolies with the responsibilities of energy generation, transmission, and distribution to meet demand. Over time, this arrangement has been plagued by limited capital and investment, weak infrastructure, poor performance, and mismanagement. ${ }^{13}$ All the stateowned energy companies operate on high long-run marginal costs, unable to attract additional capital to expand their operations, leading to inadequate investment in infrastructure and subsequently high operating costs. ${ }^{14}$ The overloaded transformer sub-stations, transmission and distribution losses, and transmission bottlenecks are contributory factors to the frequent power outages.

Existing hydroelectric stations have high capital and maintenance costs, with revenues from electricity supply financing such capital costs. ${ }^{15}$ A reduction in sales will affect the return on investment. The current state of the stations' generation capacity will require additional plants to be constructed to meet demand, which in turn requires additional capital, thus reducing overall system returns. According to the Ghana National Commission for UNESCO, about $\$ 9$ billion is required between 2014 and 2019 to raise the needed investment capital to develop the energy sector and finance its numerous initiatives including oil and gas (which alone require $\$ 5.5$ billion). Another costly factor is the high cost of technology to develop renewable energy sources such as wind, solar, and thermal which have been proposed by various stakeholders.

\section{Sustainability}

Every sustainable energy source depends on the ability to provide for fixed cost and recurrent cost [6]. A financially sustainable power sector requires that electricity is well priced to allow for full cost recovery across the entire value chain. Electricity in Ghana is not well priced. Production is not adequate, and at the same time, electricity is subsidized. The government, since 2004, has spent about $\$ 900$ million on fuel subsidies to VRA alone, an amount which is more than the cost of building the Bui dam. ${ }^{16}$ Are these subsidies sustainable, and what are the returns in the long run?

Subsidies and low tariffs have left the transmission and distribution authorities (VRA and ECG) in precarious financial states due to their inability to maintain and expand the required infrastructure. Prices have still lagged behind actual cost, and the distribution companies do not recover costs through tariffs, although tariffs have been increased repeatedly in the past decade. Tariffs are also inadequate to cover costs arising from production, distribution, and transmission losses. The operational and production efficiency of the authorities in the sector is critical to ensure the cost of supply is minimized while at the same time maintaining the financial sustainability of the sector.

\section{Growth and development implications}

Ghana's current low electrification rates are detrimental to economic growth and development. According to Alam [7], the absence of adequate energy in the production function distorts the sources of growth. Meaningful growth in supplies of energy is an indispensable source of economic growth. Some empirical studies 
have also suggested that causality runs from economic growth to energy consumption and vice versa (VlahinicDizdarevic and Zidovic [8], Amiri and Zibaei [9], Jumbe [10]). Without adequate and reliable energy in the production function, growth and development become unattainable. Capital (machinery) in the production function can only be powered by energy. Thus, without power, technology cannot be adopted for production. Technology is power driven.

The resource sector uses power to operate heavy machines for faster and efficient production. Activities related to manufacturing and production use electricity to power factories and equipment. Tertiary businesses (including the service sectors and retail) need electricity for lighting, heating, cooling, and operating computers and business equipment. Without power, the infrastructure which forms the basis of development including agriculture, transportation, technology, communication, and other basic necessities of life that depend on power will collapse. The future of industry, therefore, depends on the availability of an affordable and reliable power supply.

A lack of electrical power reduces output and creates shortages. Given that the potential losses could be significant, many firms and industries tend to insure themselves against outages by purchasing costly generators and plants, hence increasing direct costs of production. The economic cost of unreliable power supply and disruptions become very high [11]. As costs of production increase, profits plummet limiting expansion and the ability to create more jobs.

Electricity becomes the power form of choice for use in the home due to its convenience compared to firewood and kerosene. Electricity used in the residential sector accounts for about $47 \%$ of total electricity consumed in the country. ${ }^{17}$ Electricity, therefore, becomes fundamental to the growth of society and not a luxury.

\section{Energy sector initiatives and power sector reforms}

Several efforts have been made towards solving the precarious shortfalls in electricity generation capacity and supply. Successive governments have sourced loans and embarked on power sector reforms to revamp the power sector and encourage private sector participation. The World Bank, especially, has played a major role in successive power sector reforms by supporting increased private sector participation in infrastructure development. The International Development Association (IDA) of the World Bank has also embarked on several lending operations over four decades to support Ghana's power sector and to help finance virtually all major investments. The IDA helped to finance the Akosombo dam and the Kpong power plant, to rehabilitate transmission systems, to extend the grid to the northern regions, to help the Electricity Company of Ghana (ECG) to improve its distribution networks, and to provide electricity to small urban areas, district capitals, and rural areas [12]. From 1960 to date, the power sector has received significant amounts of donor support (for new construction and for rehabilitation) to ensure better electricity services to all Ghanaians.

Under the Structural Adjustment Program of 1986 (with the theme of making the private sector an engine of growth), the World Bank requested reforms in Ghana's power sector to encourage greater private sector participation [13]. Power sector reform was initiated in 1994 to regulate the monopoly power of generation, transmission, and distribution towards deregulating the market for competition and open access to transmission lines to permit new market participants to share in power generation, transmission, and distribution. ${ }^{18} \mathrm{Re}$ form was also initiated to reform the electricity tariffs that had resulted in low investment, substantial deficits of the electricity utility companies, and poor service quality ${ }^{19}$ The need to invest in additional capacity generation and infrastructure to augment increasing demand and to encourage private investment and competition in the sector were all triggered by the need for the reform [14].

The Ghana Grid Company Ltd. (GRIDCo) was established in 2006, as part of the effort to restructure the industry. By the Energy Commission Act (541) which established it, GRIDCo's primary function is to facilitate electricity transmission via delivery at power distribution centers and subsequently to all market participants, while the VRA continues its operation as a power generation company (GRIDCo). The Energy Commission and the Public Utility Regulatory Commission (PURC) were also formed in 1997 to establish performance standards for utilities and to create and maintain a healthy competitive power sector that balances the interests of utility providers and consumers (PURC, Ghana).

The Electricity Regulation also established in 2008 was to create a competitive wholesale electricity market to facilitate wholesale electricity supply and subsequently create an enabling environment to attract independent power producers. $^{20}$ Ultimately, this was to enhance Ghana's strive towards attaining an electricity generation capacity of 5000 MW by 2016 .

Presently, a national energy policy is being implemented to provide a concise outline of government's policy direction, challenges, and actions, to facilitate the effective management and development of the sector, and to provide the public with information about the government's policy goals. The policy addresses the poor quality and unreliable supply of electricity and the poor financial performance of the utility companies and helps them raise the finance needed for infrastructure 
development. In addition, the policy focuses on institutional and human resource capacity strengthening and creation of a competitive electricity market and an enabling environment to attract private investment into the sector to aid the government's multilateral sources of funding. ${ }^{21}$

Albeit there have been intentions to increase current generation capacity to at least $5000 \mathrm{MW}$, make electricity universally accessible by 2020 , and for Ghana to become a major exporter of electricity by $2015,{ }^{22}$ the current financial and infrastructural challenges pose a huge risk. The power generation expansion programs (Bui, Tema Thermal Plant 1 and 2, the Mine Reserve Plant, Asogli and Kpone Thermal Plant) which were commenced in 2007 following the 2007 energy crisis are expected to add about $1100 \mathrm{MW}$ of generation capacity, although so far only 375 MW has been added. ${ }^{23}$

According to the National Energy Policy (2010), ${ }^{24}$ Ghana needs to increase installed power capacity to $5000 \mathrm{MW}$ by 2016 . This means almost a double of the current generating capacity of 2946 MW. Thus literally, the policy is targeting an additional installed capacity of about $2100 \mathrm{MW}$ by 2016. There are a number of issues, however: (a) the Bui Dam currently has an installed capacity of $400 \mathrm{MW}$; (b) the Aboadze thermal plant has an installed capacity of $550 \mathrm{MW}$ and a maximum capacity of $682 \mathrm{MW}$; (c) the largest solar plant, the Nzema solar plant which is expected to become operational in 2015, is expected to produce $155 \mathrm{MWh}$; and (d) the mix for renewable energy is also expected to increase to about $10 \%$ in 2015. However, an energy capacity gap of 1049 MW still remains.

\section{Pathway to sustainable development in the power sector Demand-side pricing}

It is worth noting that electricity cannot be stored in large quantities, transmission and distribution losses are inevitable, electrification system is highly capital intensive, and the capacity of generation plants have their generating limit. These characteristics of the system imply that short-term measures and a focus on energy infrastructure expansion are inadequate in tackling any problems that may arise. Hence, investing in the demand side is paramount.

Economic theory suggests that efficiency in the use of inputs and resources occur when demand matches price and marginal cost (MC) of supply. The situation in Ghana shows that as demand approaches the installed generation capacity, an additional unit of power consumed adds more to the cost of generation. The marginal cost of electricity supply is elastic to changes in demand. Thus, irrespective of how electricity is priced, the marginal value of the demand for electricity declines as consumption increases. However, if electricity prices are constant and consumers pay little for it, then demand becomes perfectly inelastic. Efficiency in electricity consumption will therefore require an increase in price during periods of supply constraints to reduce demand. Final consumers must bear the real and full cost of power consumed and be made to realize the full benefits from their actions. In effect, higher prices will yield a reduction in power consumption.

In addition, since the use of hydroelectric power corresponds to about $60 \%$ of total energy use in Ghana, a practical balance between the use of hydro and thermal energy should be considered. Power should be generated from the hydro plants when consumption is below peak demand, and peak demand should be supplied by the fossil fuel thermal plants as is done in Brazil. Ghanaians must be made to pay for the fuel used in the complementary thermal generation. Although this may result in labor agitations in Ghana due to the relatively low incomes of citizens, behavioral change in the efficient use of electricity (which has been the basis of energy efficiency campaigns in Ghana) is still key. Tooraj and Pollitt [15] on the other hand have argued how demandside participation can reduce power prices. According to them, a high level of exchange of information between service providers and consumers is the first step towards demand management. Psychological motivations will also shape the behavior of consumers through a dynamic pricing system (based on incentives from the utility service providers) to expose consumers to fluctuating prices, especially during peak periods, hence lower prices for consumers who limit power consumption during peak periods.

\section{Supply-side options}

Oil and gas The discovery of oil and gas in Ghana means that Ghana can produce electricity locally and save about $\$ 350$ million annually (if production even meets a third of the country's power needs) given fluctuating crude oil prices. The oil and gas sector is seen as an anchor for the needed growth and development due to its catalytic role in industry and other sectors, with GDP expected to grow at more than an average of $10 \%$ per annum over the medium term.

Wind Along the coast of Ghana, wind speeds of 9-9.9 m/s have been recorded which could sustain wind energy with an estimated gross wind power potential of $2000 \mathrm{MW} .{ }^{25}$ Average wind speeds in Ghana show possibilities for wind power project development especially along the eastern coastal areas and mountainous regions. Currently, the Volta River Authority's wind project seeks to install about 100 to $150 \mathrm{MW}$ of capacity. The Energy Commission in 2015 also granted 
provisional licenses for the development of about 490MW capacity of wind farms along the coast of Ghana. ${ }^{26}$

Solar Ghana is endowed with solar resources which allow for very high potential in both grid and off-grid solar power solutions. The solar potential is estimated at 35 EJ (exajoules) which is about 100 times the present power consumption with annual average working hours of 2670 equivalent to $53,000 \mathrm{MWh}$ a year. ${ }^{27}$ The biggest solar energy plant in Africa, the Nzema project in the Western region of Ghana, scheduled to begin construction by the end of 2015, is projected to provide electricity to over 100,000 households. The $155-\mathrm{MW}$ plant is expected to increase the nation's electricity generating capacity by $6 \%$.

Nuclear Although there have been qualms about the nuclear potential of the country, nuclear power can be considered a viable option in the national energy mix due to the increasing power demand and the country's quest towards achieving middle-income status. Ghana, in addition to 44 other countries without nuclear power, is willing to participate in technical cooperation projects to introduce nuclear power in the energy mix. ${ }^{28}$ According to the Ghana Atomic Energy Commission, Ghana is making steady progress to go nuclear for its electricity generation.

Private sector participation Given the alternatives, a focused and forward-looking leadership, robust power sector policies, a sound political and public will, and (most important of all) private sector participation are all needed to develop efficient power sources for sustainability in the sector. Since 1994, power sector reforms have aimed at increasing private sector participation in the sector. Although there are policies and plans ongoing to harness the full potential of some of the energy mix, leaving the power sector to the public sector to manage will be very costly and inefficient. The public sector has mostly been associated with mismanagement and may lack the necessary capacity and funds to fully harness the potential of the various energy sources.

Harnessing both pathways-demand-side and supplyside options-through the efficient use of energy, provision of environmentally friendly energy sources, and ensuring sound transmission, distribution, and reliable supply of power will ensure that the services that energy enables (better lighting, cooking, communications, transportation, income generation processes, and other services) will advance sustainable development by improving human, social, economic, and environmental conditions.

\section{Conclusions}

Exploitation of hydropower is an attractive power source because it is renewable, clean, sustainable, and efficient and it is considered a key feature of development especially in developing countries [16]. Environmental hazards and climate changes diminish the prospects for hydropower, which is mainly seen in the reduced water levels due to increased reservoir evaporation and droughts. This means that a power crisis is inevitable should water levels go down. Thus, with rising power demand, to what extent and for how long can hydroelectric power be relied upon to meet power needs? As the quest for growth and development is paramount, will Ghana be able to meet its power demand as it continues to grow? How can Ghana leverage on its potential power sources to facilitate the needed accelerated sustainable growth and transformation? For Ghana to attain accelerated growth and transformation, the power sector is critical and the problems need a comprehensive approach through a mix of demand- and supply-side options to provide a cost effective solution. Ghana's energy policy over the years has focused on alternative renewable energy such as the efficient use of solar and wind in the national energy mix. However, to date, the share of renewables in the energy mix is less than $5 \%$ of total energy generated. ${ }^{29}$ Ghana's energy policy must create and harness a diversity of resources and to reduce delivery risks in these resources. It is clear that Ghana will have to expand its energy infrastructure and diversify its installed capacity to improve supply frequency and reliability in a way that is sustainable.

\section{Endnotes}

${ }^{1}$ Source: Data obtained from Ghana Wholesale Power Reliability Assessment (2010) Final report. Power Systems Energy Consulting, GRIDCo.

${ }^{2}$ Source: Volta River Development Act (Act 46) (1961) Volta River Authority, Ghana.

${ }^{3}$ Source: Ghana Wholesale Power Reliability Assessment (2010) Final report. Power Systems Energy Consulting, GRIDCo.

${ }^{4}$ Source: Energy Commission (2015) Energy supply and demand outlook for Ghana. Energy Commission.

${ }^{5}$ Source: Energy Commission (2013) Energy outlook for Ghana. Energy Commission.

${ }^{6}$ Source: Energy Commission (2014) Energy supply and demand outlook for Ghana. Energy Commission.

${ }^{7}$ Source: UNICEF (2014) Generation 2030, Africa.

${ }^{8}$ Source: Ghana Grid Company Limited (GRIDCo) (2010) Annual report.

${ }^{9}$ Source: Energy Commission (2015) Energy supply and demand outlook for Ghana. Energy Commission.

${ }^{10}$ Source: Energy Commission (2015) Energy supply and demand outlook for Ghana. Energy Commission. 
${ }^{11}$ Source: Energy Commission (2014) Energy supply and demand outlook for Ghana. Energy Commission.

${ }^{12}$ Source: Ghana Growth and Development Platform (2015) Of "Dumsor" and Ghana's energy sector challenges: Part 3 http://ghanagdp.org/. Accessed 3 July 2015.

${ }^{13}$ Source: Energy Sector Strategy and Development Plan (2010) Ministry of Energy. Ghana.

${ }^{14}$ Source: Energy Sector Strategy and Development Plan (2010) Ministry of Energy. Ghana.

${ }^{15}$ Source: Energy Sector Strategy and Development Plan (2010) Ministry of Energy. Ghana.

${ }^{16}$ Source: Energy Sector Strategy and Development Plan (2010) Ministry of Energy. Ghana.

${ }^{17}$ Source: Energy Commission (2014) Energy supply and demand outlook for Ghana. Energy Commission.

${ }^{18}$ Source: Ghana Grid Company Limited (GRIDCo) (2010) Annual report.

${ }^{19}$ Source: Ghana Wholesale Power Reliability Assessment (2010) Final report. Power Systems Energy Consulting, GRIDCo.

${ }^{20}$ Source: Energy Commission (2015) Energy supply and demand outlook for Ghana. Energy Commission.

${ }^{21}$ Source: National Energy Policy (2010) Ministry of Energy, Ghana.

${ }^{22}$ Source: National Energy Policy (2010) Ministry of Energy, Ghana.

${ }^{23}$ Source: Energy Commission (2015) Energy supply and demand outlook for Ghana. Energy Commission.

${ }^{24}$ Source: National Energy Policy (2010) Ministry of Energy, Ghana.

${ }^{25}$ Source: Energy Commission (2015) Ongoing initiatives to accelerate sustainable uptake of renewable energy. Presentation at the Renewable Energy Fair, November 2015, Accra, Ghana.

${ }^{26}$ Source: Energy Commission (2015) Ongoing initiatives to accelerate sustainable uptake of renewable energy. Presentation at the Renewable Energy Fair, November 2015, Accra, Ghana.

${ }^{27}$ Source: UNEP (2013) Emission reduction profile Ghana.

${ }^{28}$ Data obtained from World Nuclear Association (2014).

${ }^{29}$ Source: Energy Commission (2014) Energy supply and demand outlook for Ghana. Energy Commission.

\section{Authors' information}

Maame Esi Eshun is a Research Associate at the African Center for Economic Transformation, Accra, Ghana (Email: meeshun@acetforafrica.org). Joe AmoakoTuffour (Ph.D) is the Director of Research at the African Center for Economic

Transformation, Accra, Ghana (Email: jtuffour@acetforafrica.org).

Received: 8 September 2015 Accepted: 2 March 2016

Published online: 08 April 2016

\section{References}

1. Adusei L (2012) Energy security and the future of Ghana. Accessed 3 July 2015. Available at: http://newsghana.com.gh/energy-security-andthe-future-of-ghana/

2. ISSER (2005) Guide to Electric Power in Ghana. Resource Center for Energy Economics and Regulation. Institute of Statistical, Social and Economic Research, University of Ghana, Legon

3. Kaya YK (1971) Volta Dam: an example of international cooperation. Accessed 27 June 2015. Available at: http://www.politics.ankara.edu.tr/dergi/ tybook/11/Yahya_Kemal_Kaya.pdf

4. Meng J (2004) Ghana's development, miracle or mirage? Accessed 15 December 2015. Available at: http://www.joycemeng.com/writings/ ghana.pdf

5. Asante FA, Clottey EA (2007) Ghana's electricity industry. Accessed 3 July 2015. Available at: http://www.esi-africa.com/ghana-s-electricity-industry/.

6. International Renewable Energy Agency (IRENA) (2012) Renewable energy technologies: cost analysis series. IRENA, Vol. 1 Issue 3/5, 2012.

7. Alam MS (2006) Economic growth with energy. Munich Personal RePEC Archive (MPRA). Accessed 25 December 2006

8. Vlahinic-Dizdarevic N, Zidovic S (2010) The role of energy in economic growth: the case of Croatia. Proceedings of Rijeka Faculty of Economics, Journal of Economics and Business, Vol 28 (1):35-60

9. Amiri A, Zibaei M (2012) Granger causality between energy use and economic growth in France using geostatistical methods. Munich Personal RePEc Archive (MPRA) Paper 36357

10. Jumbe CBL (2004) Cointegration and Causality between Electricity Consumption and GDP: Empirical Evidence from Malawi. Energy Economics 26:61-68

11. Foster V, Steinbucks J (2008) Paying the price for unreliable power supplies: in-house generation of electricity by firms in Africa. AICD. Accessed 20 June 2015. Available at: http://www.infrastructureafrica.org/system/files/library/ 2011/05/WP02_Own_generation.pdf

12. IDA (2009) IDA at work; Ghana's concerns. Accessed 12 May 2015 Available at: http://siteresources.worldbank.org/IDA/Resources/IDA-Ghana.pdf

13. Marsden K, Belot T (1987) Private enterprise in Africa. Creating a better environment. World Bank Discussion Papers

14. Clark A, Davis M, Eberhard A, Gratwick K, Wamukonya N (2005) Power sector reform in Africa; assessing the impact on poor people. University of Capetown, for ESMAP/World Bank.

15. Tooraj J, Pollitt MG (2011) The future of electricity demand: customers, citizens, and loads. Cambridge University Press, Cambridge, United Kingdom.

16. Harrison GP, Whittington HW, Gundry SW (2000) Hydropower impacts and climate change. Available at http://www.eng.ed.ac.uk/ gph/publications/ GPHUpec98.pdf.

doi:10.1186/s13705-016-0075-y

Cite this article as: Eshun and Amoako-Tuffour: A review of the trends in Ghana's

power sector. Energy, Sustainability and Society 20165

\section{Competing interests}

The authors declare that they have no competing interests.

MEE is the lead author who collected and analyzed the data and provided the write up on the paper. JAT reviewed and provided input on the structure, content, and technical aspects of the paper. Both authors read and approved the manuscript. 